\title{
Observações biológicas e meteorológicas feitas na Ilha de Trindade.(*)
}

\section{Rudolf Barth}

Por intermédio do Departamento de Hidrografia e Navegação da Marinha do Brasil, tive a oportunidade de visitar a Ilha de Trindade, no período de 26 de agôsto a 14 de setembro de 1957. Este citado Departamento, dentro do plano dos trabalhos do Ano Geofísico Internacional, executa trabalhos e estidos oceanográficos, meteorológicos e hidrobiológicos ao sul do Oceano Atlântico, incluindo a instalação de um Pôsto Meteorológico (inclusive serviço de radiossondagem, na citada ilha).

Antes de entrar em pormenores, quero agradecer ao Diretor do Departamento de Hidrografia e Navegação da Marinha, Almirante Jorge da Silva Leite, bem como ao Vice-Diretor Comandante CMG Levi Pena Arrão Rei, pela gentileza com que me possibilitaram esta viagem a bordo do NE "Almirante Saldanha", bem como pela permissão que tive de aproveitar-me de tôdas as instalações do navio. Não posso deixar de àgradecer ao Comandante do NE "Almirante Saldanha", CMG José Santos de Saldanha da Gama, ao seu Imediato, CC Edimar Aché Cordeiro, bem como a tôda a oficialidade do navio e da guarnição da Ilha, pelo tratamento amigável que recebi e pela grande ajuda oferecida por todos.

A Ilha de Trindade, situada a 20030' $\mathrm{S}$ e 29020' $\mathrm{W}$, é de origem vulcânica. Não pertence mais à plataforma continental (fig. 1), mas ergue-se, como uma única coluna, de uma profundidade de 4.000 a $5.000 \mathrm{~m}$, numa distância de 600 milhas da costa do Brasil, na limitação ocidental da Bacia do Brasil, que, por, sua vez, representa uma extensa depressão do fundo do mar (até $7.000 \mathrm{~m}$ ) a leste da elevação central do Atlântico. Numa distância de 30 milhas a leste da ilha encontramos uma formação semelhante, que é o arquipélago de Martin Vaz bem visível da Trindade em dias claros. Em contradição aos mapas geográficos, a Trindade e êste grupo não possuem uma base comum, pois, pelas sondagens provisórias, foi constatada uma profundidade de alguns mil metros entre estas duas porções de terra. A figura 1 demonstra um esquema de perfil que, até a Marinha terminar a sondagem, é de caráter provisório.

(*) Trabalho realizado sob os auspícios do Conselho Naciona! de Pesquisas. Recebido para publicação em 13-11-57. 
A ilha possui uma extensão, no sentido NW para $\mathrm{SE}$, de $5 \mathrm{~km}$, e, no sentido NE para $\mathrm{SW}$, de $2,5 \mathrm{~km}$, e é circundada por uma plataforma (até $200 \mathrm{~m}$ de profundidade) que termina numa distância de 2 a $3 \mathrm{mi}$ lhas da costa. Grande parte do litoral, especialmente as enseadas e menores reentrâncias, possuem um banco de corais (fig. 2), que protege a

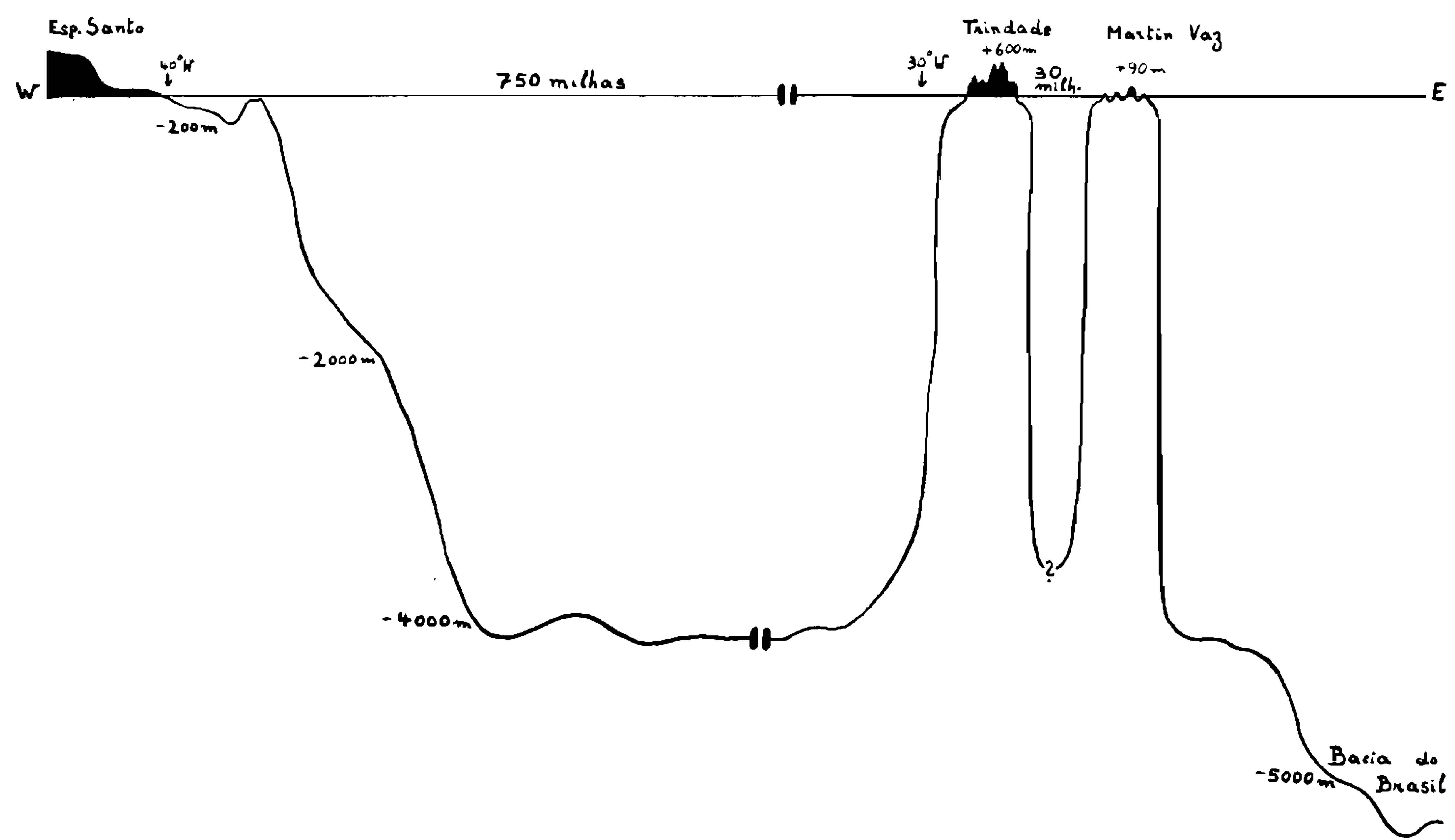

Fig. 1 - Esquema de um perfil pelo Atlântico entre Brasil e a Bacia do Brasil (encurtacin e sem os altos fundos como o Banco de Jasseur perto de $36^{\circ} \mathrm{W}$ ).

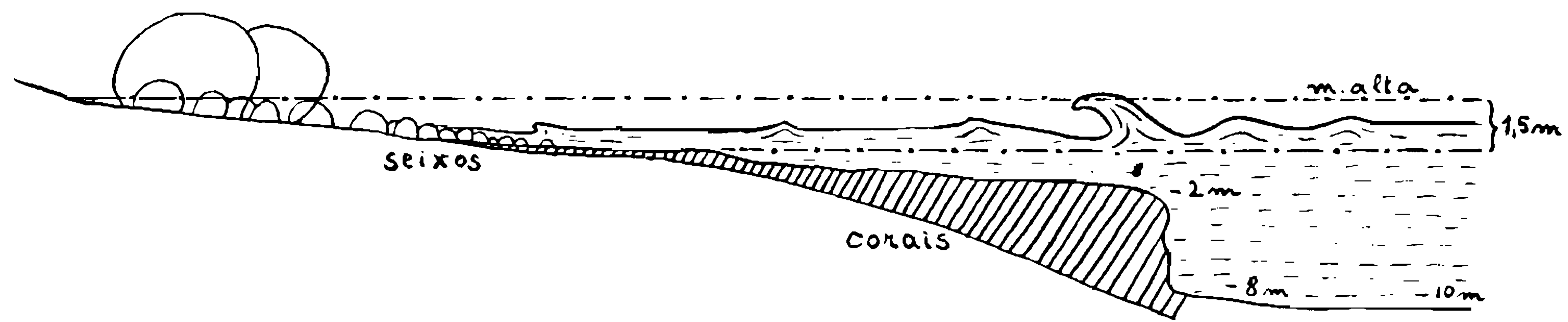

Fig. 2 - Perfil esquemático da orla da Ilha de Trindade.

orla do mar. Esta formação calcárea originada de corais do gênero Lithothamnion que, depois de destruição ocasional, pelo mar agitado, sempre se regenera, evita que o mar carregue o material da ilha, decomposto pela erosão. Mesmo sendo esta última espetacularmente intensa e acelerada, a ilha, apesar do abaixamento das suas elevações (até $600 \mathrm{~m}$ de altitude), não corre perigo de desaparecer em futuro próximo, pois, pelo banco coralino, especialmente nas enseadas, que representam os pontos mais vulneráveis da ilha, a arrebentação fica afastada da terra até 50 ou mais metros. Ainda não conhecemos a grossura da formação coralina, mas podemos considerá-la bastante forte, 
pois a altura do barranco na zona da arrebentação é de 5 a $10 \mathrm{~m}$ (fig. 2), formando realmente um muro de proteção que cresce ainda permanentemente.

A porção terrestre da ilha, atualmente, dá um aspecto típico de uma formação vulcânica de origem mais recente, caracterizada por um relêvo muito movimentado com picos e encostas íngremes, até verticais, vales profundos com muito material rochoso e decomposto, restos de crateras e rampas formadas pelo desmoronamento dos paredões e elevações (fig. 3). Encontramos picos altos que representam os cones

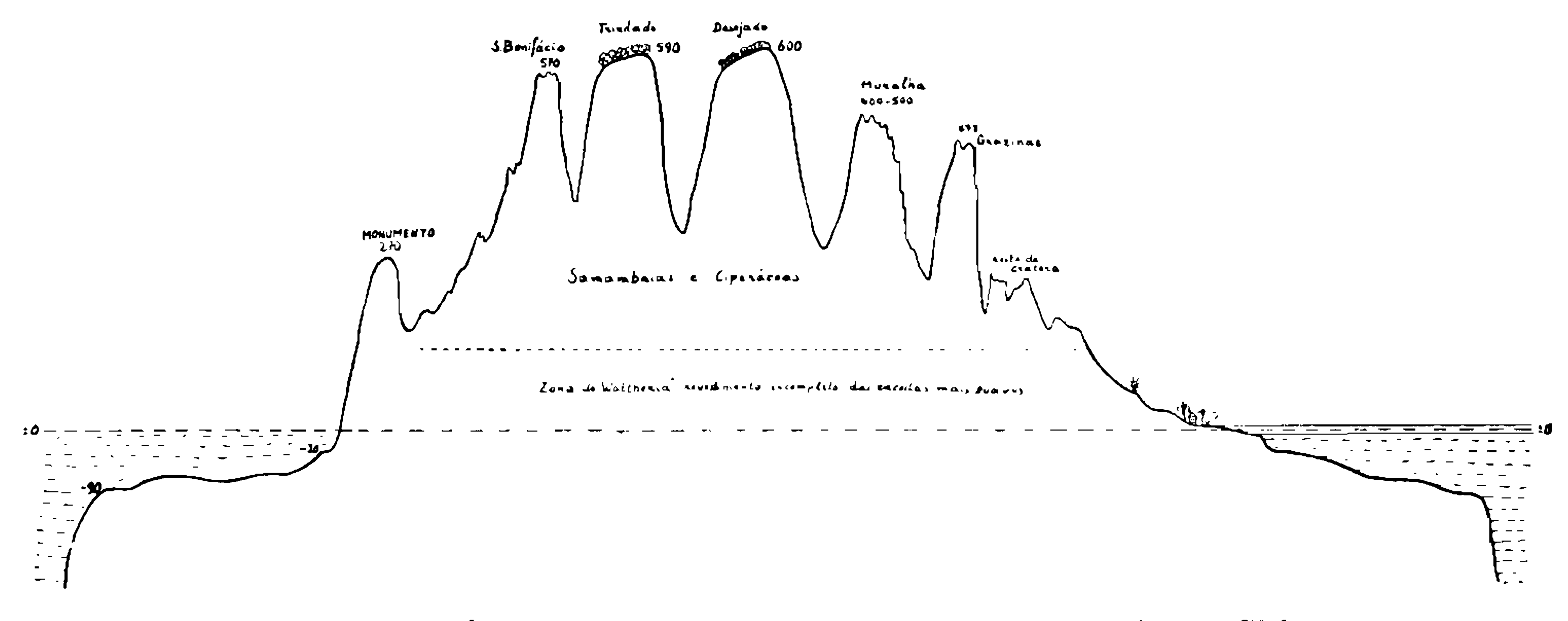

Fig. 3 - Corte esquemático pela Iha de Trindade no sentido NE - SW.

vulcânicos, e moros compostos puramente de cinzas que permitem, ainda hoje, observar as camadas quase horizontais, conforme a seqüencia das erupções (apresentando um aspecto de sedimentos marinhos), e que foram, secundàriamente, modificadas por pressão e calor, sendo, de vez em quando, intercaladas por camadas de lava solidificada. Além das poucas praias, a ilha não tem partes planas; sòmente na região leste as encostas de algumas colinas são de inclinação mais suave. Não me cabe dar uma apresentação geográfica e geológica da ilha, mas, a fim de compreender a distribuição da vegetação, tirei 25 amostras do solo para analizar a composição do mesmo e examinar a microfauna contida neste. Passo, em seguida, a apresentar o resumo do exame provisório das citadas amostras:

A matéria inorgânica é pouco desintegrada; a substância coloidal é muito reduzida. Tôdas as amostras possuem grande quantidade de cristais, partículas de cinzas e lava com diâmetros de $1 \mathrm{~mm}$ até $0,1 \mathrm{~mm}$ (aproximadamente 40 a $55 \%$ do volume). O grupo das partículas com diâmetros de 100 micra a 1 micron é reduzido (aproximadamente entre 30 e $40 \%$ do volume). O resto, com diâmetros menores do que $1 \mathrm{mi}$ cron, é material bastante pesado que demonstra uma velocidade de sedimentação muito acelerada, em comparação com uma amostra tirada no terreno do Instituto Oswaldo Cruz. A turvação restante, que indica o grau de substâncias coloidais, depois de 15 minutos, é muito reduzida. 
A amostra mais rica em Protozoários foi, lògicamente, a do lôdo do córrego da Praia dos Portuguêses, e a tirada do sedimento do mesmo córrego. Encontramos:

Diatomacea: 13 espécies, numerosas

Flagellata: 4 espécies (Phytomonadina)

Conjugales: 2 espécies

Ciliata: 5 espécies, extremamente pequeras

Amoeba: 1 espécie

Thecamoeba: 3 espécies

Cyanophycea: 1 espécie

Bactérias: várias formas, mas em número muito reduzido.

Extremamente pobre em microfauna foi a amostra colhida em baixo da vegetação rasteira de Waltheria americana. Foram encontrados sòmente poucos Nematódeos de vida livre.

As amostras, que foram tiradas na época sêca do inverno, indicam que as plantas não podem aproveitar-se da riqueza mineral do solo em virtude da escassez de microorganismos. Precisa-se de uma observação na época mais úmida, a fim de que se possa fazer comparação. Para melhorar o solo, a fim de possibilitar a horticultura em pequena escala, para abastecer um pequeno número de pessoas com legumes verdes, basta adubar a terra com estrume natural que contem, em geral, suficientemente os microorganismos.

\section{Observações faunisticas}

As observações referem-se sòmente à fauna terrestre; o rico material marinho não foi incluído nesta comunicação, pois merece um estudo especial. O número das espécies encontradas, especialmente o dos insetos, não corresponde ao das formas que realmente habitam a ilha, pois coletamos e observamos, na época sêca do ano, supondo, assim, que na estação mais úmida o número das espécies deve aumentar consideràvelmente. Damos, em seguida, uma apresentação das nossas observações faunísticas:

\section{Vermes:}

Além de poucos Nematódeos do solo, foi encontrada uma espécie de Oligochaeta (minhoca comum), ainda não classificada. Vive esta sòmente nas margens da parte baixa do córrego da Praia dos Portuguêses, onde o solo é mais úmido e humoso.

\section{Mollusca:}

Foi encontrado grande número de caracóis de uma espécie de caramujo terrestre (vertentes dos Picos do Vigia e N. S. de Lourdes). Os animais vivos não foram localizados. Os caracóis acúmulam-se nas ravinas, enterrados na areia; todos são bastante gastos, cutícula e, par- 
cialmente, a camada prismática já desapareceram de modo que podemos concluir que os animais já morreram há alguns anos. Em cima do lugar, onde se encontram os caracóis, não existe nenhum vestígio de vegetação, além de alguns restos de liquens que formam pequenas crostas sôbre algumas pedras; examinei também êstes lugares sem encontrar caramujos vivos.

Arthropoda:

Crustacea:

Além de uma espécie do grupo Catometopa (Brachiura), chamada "siri", que vive na água salgada e raras vêzes aparece na orla do mar, encontramos duas espécies de crustáceos, característicos da ilha, dos quais o Grapsus grapsus, em grande número, vive nas pedras do banco coralino e da orla; esta espécie onívora penetra, às vêzes, na terra, por exemplo na Praia do Príncipe, onde foram encontrados muitos exemplares num lugar úmido (água doce), alimentando-se de algas e musgos. A outra espécie é Gecarcinus lagostoma, de preferência fitófaga, encontrada em grande quantidade em tôdas as partes da ilha até o alto dos picos, onde existe vegetação. Vivem êstes animais embaixo das pedras, cavando tubos até $1 \mathrm{~m}$ de profundidade, aproveitando-se da umidade existente aí, bem como da água de condensação que se precipita sôbre a superfície das pedras durante a noite: As pedras acumulam o calor do sol e irradiam-no, ràpidamente, ao anoitecer, de modo que a umidade se condensa nas superfícies mais frias do que o ar. A quantidade de água basta para escorrer e molhar a terra na base da pedra. Observamos várias vêzes exemplares de Gecarcinus, na primeira hora do dia, lambendo o líquido que pingou das pedras. Outro grupo de Crustáceos são os Isopoda que vivem, em baixo das pedras, em grande quantidade; constatamos várias espécies de Oniscidae e Armadillidiidae.

\section{Myriapoda:}

Não foram observados Diplópodes. Dos Chilopoda ocorre uma espécie pequena e que vive no mesmo ambiente dos Isópodes.

Insetos:

Thysanura:

Uma espécie de Lepismatidae foi encontrada na "Casa de Rádio" (animal provàvelmente introduzido com o material da instalação). Dos Machilidae observamos uma espécie embaixo de pedras, nas Praias dos Portuguêses e dos Cabritos e perto da Pedra do Tubarão. Várias espécies de Collembola vivem, embaixo das pedras, em tôdas as partes da ilha.

\section{Blattaria:}

Ocorrem nas casas, provàvelmente introduzidas pelo material de abastecimento da guarnição, duas espécies de baratas: Blatta germa- 
nica e Periplaneta americana. Embaixo das pedras, na parte norte da ilha, vivem mais duas espécies, das quais uma, provàvelmente, Periplaneta australasiae, é muito freqüente, enquanto que a outra (espécie áptera) é encontrada sòmente em alguns lugares em cima das residências.

\section{Orthoptera:}

Nas pedras, ao longo das Praias (dos Portuguêses e do Andrada), ocorrem freqüentemente muitos exemplares de um Gryllidae que não sobe nas encostas dos picos. Dos Acridiidae é muito comum a Schistocerca paranensis, o gafanhoto migratório que causa os grandes danos na Argentina, Uruguai e na parte sul do Brasil. Encontramos êste Ortóptero em grande quantidade em tôdas as partes onde existe qualquer vegetação, especialmente nas encostas em cima das Praias dos Portuguêses e do Andrada, no vale que dá para a Praia do Príncipe e no planalto em cima da Praia dos Cabritos. A espécie, adultos e todos os estados larvais, ocorrem em quantidade tão elevada que já hoje causam certos danos à vegetação de maneira que, com uma reprodução dêstes animais um pouco mais elevada, a ilha corre perigo de enfrentar uma verdadeira praga. Além desta espécie encontramos outra (braquíptera) em número reduzido.

\section{Psocoptera:}

Uma espécie foi encontrada numa pedra do córrego da Praia dos Portuguêses.

\section{Anoplura:}

Dêstes parasitas sòmente os cabritos possuem uma espécie, enquanto que em porcos e carneiros não observamos nenhuma espécie.

\section{Chrysopidae:}

Foi encontrada uma espécie na "Casa de Rádio", atraída pela luz.

\section{Dermaptera:}

Nas Praias é comum a espécie Labidura riparia, que cava profundas galerias na areia. Encontramos esta em quantidade embaixo de pedras e, especialmente, em cadáveres de porcos.

\section{Homoptera:}

No córrego, na Praia dos Portuguêses, perto das casas, onde existe alguns metros quadrados de terra coberta por capim, vive uma espécie de Aphidae (pulgão das plantas), sempre visitadas por formigas do gênero Pheidole. No mesmo lugar encontramos algumas colônias de Coccidae. 


\section{Odonata:}

É comum uma espécie do gênero Aeschna, cuja larva encontramos freqüentemente na água do córrego da Praia do Portuguêses.

\section{Coleoptera:}

$\mathrm{Na}$ água do córrego da Praia dos Portuguêses coletamos uma larva de um pequeno Hidrofilídeo. Num cadáver de porco encontramos muitos exemplares de um Dermestídeo, provàvelmente Dermestes maculatus, adultos e tôdas as formas larvais. No mesmo ambiente vive um outro Coleóptero, ainda não classificado (com larvas).

\section{Diptera:}

Nas residências e redondezas existem muitas moscas caseiras (Musca doméstica, Drosophilidae, Eurioma erythrogaster, Lucillia, Piophila casei), introduzidas com o material da guarnição, e que se alimentam pelos esgôtos e lixo e pelas fezes de origem animal e humana nesta região; depois do acabamento das novas construções e das instalações sanitárias, o número dêstes possíveis transmissores de doenças contagiosas automàticamente diminuirá. Na "Casa do Rádio", atraído pela luz elétrica, coletamos um pequeno Tipulídeo e alguns exemplares de um Nematócero pequeno. Sôbre cadáveres, nos restos de comida e sôbre fezes de animais e homens encontramos muitas outras formas de Dípteros (Sarcophagidae etc.). Numa pedra, onde pouco antes passou um rebanho de cabritos, observamos um exemplares de Hipoboscidae. Algumas larvas de Chironomidae ocorrem no lôdo das águas estagnadas do córrego da Praia dos Portuguêses e das duas reprêsas do mesmo.

\section{Hymenoptera:}

Observamos duas espécies de formigas, ambas muito freqüentes, uma do gênero Pheidole, outra ainda não classificada. A Pheidole penetra freqüentemente nas casas.

\section{Lepidoptera:}

Formas diurnas não foram observadas. Formas noturnas: Observamos muitas espécies e exemplares de Microlepidópteros, atraídas, à noite, pela luz, bem como durante as caminhadas pela vegetação rasteira das encostas. Verificamos que as larvas de várias espécies se alimentam de Waltheria americana, em cujos caules elas roem as suas galerias; em conseqüência disso existem muitas hastes desta planta, mortas e sêcas.

São muito comuns várias (oito ou nove) espécies de Noctuídeos, que, aos milhares, chegam à luz ("Casa do Rádio", Frigorífico) ou, mesmo durante o dia, voam por entre as pedras das praias e sôbre a vegetação. A espécie, mais freqüentemente encontrada, é a Mocis repandx, cuja lagarta é conhecida como "bicho do milho"; observamos esta larva comendo as fôlhas de várias plantas. 


\section{Arachnida:}

Observamos numerosas espécies de aranhas entre as pedras, na vegetação, bem como nas casas; porém, não foram colecionadas por nós, pois, poucos dias antes, o especialista dêste grupo dos Artrópodes, Dr. Wolfgang Buecherl do Instituto Butantan, passou pela ilha coletando os objetos da sua especialidade. Observamos que as aranhas se acumulam especialmente em lugares onde sempre há bastante insetos, em geral Dípteros. Mencionamos as teias de uma espécie, perto do gênero Tetragnatha, que são fabricadas, em posição vertical, sôbre a superfície de águas estagnadas onde existe grande número de pequenos Dípteros.

Nas amostras da terra observamos algumas formas de Ácaros de vida livre (Gamasiidae?, Thrombidiformes), porém em número muito reduzido. Ixodidae (carrapatos) não foram encontrados, pois todos os Mamíferos da ilha, examinados por nós, não possuiram êstes parasitas.

Vertebrados:

Pisces:

Peixes de água doce não existem na ilha.

\section{Amphibia:}

Batráquios não foram observados. Reptilia:

O único réptil da ilha é a grande tartaruga, Chelonia mydas, que em abril e maio, vem do alto mar às praias para desovar. Contamos na Praia do Andrada, aproximadamente, 750 antigas posturas, calculando o número total para tôda a ilha em 1.500 até 1.600 posturas anuais. São as seguintes as praias visitadas pelas tartarugas :

Pria dos Portuguêses (uma pequena parte a leste)

Praia do Andrada

Praia das Tartarugas

Praia do Príncipe

Pequena Praia, antes do Paredão

Praia do Paredão.

Tôdas as posturas (não observamos nenhum sinal de exceção) foram descobertas pelos porcos, que devoraram quase todos os ovos, deixando apenas as cascas brancas, encontradas nos profundos buracos de um metro ou mais de diâmetro, bem como, levado pelo vento, sôbre a areia das praias. Poucos ovos, ocasionalmente não encontrados pelos porcos, completaram a evolução e os filhotes, de quase 12 a $15 \mathrm{~cm}$ de comprimento, foram à água. Dêstes poucos sòmente alguns chegaram aí, pois o João Grande (Fregata minor), gaivota de rapina, caçou alguns e os grandes siris decapitaram os outros ao chegar à orla (Observações comunicadas pelo pessoal da guarnição da ilha). Encontramos alguns exemplares de filhotes decapitados. Uma postura de tartaruga 
conta de 150 até 200 ovos ou mais. Continuando êste massacre pelos porcos, no decorrer de poucos anos, o número de tartarugas continuará a diminuir até êstes animais, documentos vivos de uma época paleontológica, já passada há centenas de milhões de anos, desaparecerão do único lugar onde existem hoje em território brasileiro em número consideràvelmente alto. A dizimação dos filhotes pelos siris e aves é uma eliminação de medida natural que não representa nenhum perigo para a permanência dêste animal inofensivo.

Aves:

Tôdas as aves da ilha são formas marinhas. Observamos:

Anous minutus - Andorinho do Mar

Fregata minor - João Grande

Gygis alba - Pombo do Mar

Pterodroma arminjoniana - Grazina

Sula sula - Atobá de pé vermelho

Sula dactylatra - Atobá de face preta.

O número dos exemplares de cada espécie é extremamente pequeno. Isto, provàvelmente, está relacionado à pobreza em peixes que encontramos, pelo menos nesta época, nas águas costeiras da ilha. A grande parte dos peixes vive dentro da zona de arrebentação (peixes que se alimentam de corais), onde as aves não conseguem pescar.

Observamos nidificações de aves nos seguintes lugares (sempre em paredes verticais, onde os gatos não podem subir):

Pico de Desejado: Na vegetação arbórea do seu cume nidifica, provàvelmente, a Sula sula (ninhos não encontrados; observamos os casais que, voando em linha reta, chegaram, de todos os lados, do alto mar e sempre procurando êste pico alto).

Pico leste dos Cinco Farilhões: Com exceção de Sula sula, tôdas as demais espécies; as paredes do pico, em grande extensão, são brancos pelas fezes.

Pico do Paredão: Anous minutus.

Pão-de-Açúcar: Anous minutus e Pterodroma arminjoniana.

Encontramos alguns pontos onde antigamente as aves nidificaram; as pedras dêstes lugares ainda demonstram as manchas brancas das fezes.

\section{Mammalia:}

Originàriamente não viveram mamíferos na ilha.

Pelo homem foram introduzidas várias espécies:

Mus musculus - Camundongo caseiro

Felis ochreata domestica - Gato doméstico

Ovis aries - Carneiro

Capra hircus - Cabrito

Sus scrofa domestica - Porco doméstico. 
Mus musculus: Foi introduzido na ilha com o material de abastecimento; encontra-se agora nas casas e sob a madeira perto das novas construções.

Felis ochreata domestica: Existe em pequeno número. Observamos um exemplar na vertente leste do Pico do Vigia, de côr preta-branca e de corpo muito forte. Foram encontrados freqüentemente rastros do animal nas praias onde os gatos controlaram a orla do mar em procura de alimento que o mar joga à praia.

Ovis aries et Capra hircus: Não se sabe bem quem foi que soltou os carneiros e cabritos na ilha. Atualmente estas duas espécies vivem em rebanhos de 10 a 30 , às vêzes até 60 ou mais, andando em tôda a parte da ilha, onde se encontra vegetação. Observamos que os cabritos vão pastando bem nos cumes mais elevados da ilha como nas partes ao nível do mar (Praia do Andrada e Praia do Príncipe), enquanto que os carneiros preferem as regiões altas e apenas raramente descem para as vertentes baixas. O número total de cabritos na ilha deve ser, aproximadamente, 250 até 300 cabeças, o dos carneiros um pouco menor, talvez perto de 200. Êstes dois herbívoros alimentam-se de todos os componentes da vegetação com exceção das samambaias; observamos os cabritos devorando mesmo as plantas espinhosas das praias. O alimento principal são as fôlhas de Waltheria americana que, em grande extensão, reveste algumas colinas e o planalto em cima da Praia dos Cabritos. Os cabritos, além dêste pasto, comem também as fôlhas das poucas árvores e roem a cascas dos troncos, como conseguimos observar no Pico de Trindade e nos troncos mortos que foram levados pela água para os vales; nestes troncos podem-se observar, ainda hoje, as marcas dos dentes dos cabritos. O estado físico das duas espécies não é excelente, porém não são magras. A estrutura do corpo não se difere da das formas que o homem cria; sòmente o pêlo é mais comprido, especialmente o dos bodes velhos. A carne dos cabritos e carneiros é de boa qualidade.

Sus scrofa doméstica: Os porcos, segundo os antigos documentos, foram introduzidos já em 1700 pelo astrônomo inglês Halley, mas as expedições seguidas (Navio "Venus" em 1784; Ross em 1839 e outros) provàvelmente, soltaram também alguns exemplares. O porco doméstico, descendente do javalí europeu, é do ponto de vista hereditário um animal instável, isto é, num ambiente livre, sem o cuidado do homem, depois de um certo número de anos e gerações, êle volta mais e mais à forma primitiva. Observamos êste fato nos porcos abatidos na ilha durante a viagem, bem como nos cadáveres e nas ossadas encontradas freqüentemente. Os sinais de forma selvagem são, além do comportamento, os seguintes, comparados com os da forma caseira:

Região do ombro mais alta e mais forte do que a da bacia.

Musculatura do pescoço reforçada.

Frente da cabeça e crista do nariz quase em linha reta.

Focinho prolongado.

Presas fortes e muito divergentes 
Cristas occipitais (inserção da musculatura do pescoço) muito salientes.

Cauda comprida e reta, com tufo terminal de pêlos.

Pêlo duro e comprido de côr preta.

Corpo comprimido lateralmente.

Orelhas eretas.

Alimentam-se os porcos, como provou o exame do conteúdo de estômagos, de preferência de vegetais, especialmente de rizomas e raízes de Waltheria americana e de outras plantas não identificadas, bem como de fôlhas e raízes de Ciperáceas. Além dos ovos das tartarugas, comem também cabritos e carneiros caídos e filhotes dos mesmos. Sinais de canibalismo não foram observados. Não acredito que êles devorem muitos peixes, pois a carne de dois exemplares que lá comemos foi excelente e gostosa, sem sabor de peixe; pode ser que, em outras épocas do ano, o mar joga mais peixe às praias; faltam-nos ainda observações para a comparação.

\section{Observações ecológicas}

A vegetação da ilha está em forte regressão. Os antigos documentos de visitantes dos séculos 18 e 19 falam de matas de Pau-Brasil e outras madeiras em regiões extensas. Sem tomar em consideração estas notícias, em parte duvidosas, várias observações provam esta regressão:

Em tôda parte da ilha encontramos, nas ravinas, córregos e "canõns" (vales encaixados), muitos troncos mortos, com diâmetros de 25 até $30 \mathrm{~cm}$. Êstes troncos são testemunhas do dessecamento contínuo que, por sua parte, favorece e acelera a erosão. A causa do comêço dêste processo de destruição da terra, é, sem qualquer dúvida, o resultado da introdução dos grandes animais que desequilibraram a natureza original da ilha. Encontramos tais troncos na grande ravina que desce do Pico das Grazinas, onde hoje sòmente crescem algumas pequenas samambaias e ciperáceas, mas nenhuma árvore. O mesmo fato ocorre nos profundos "canõns" e ravinas que cortam os vertentes dos Picos Verde e Vermelho, picos êstes que hoje estão completamente sem revestimento vegetal. A erosão começou pela pastagem permanente dos rebanhos de cabritos e carneiros que, não sòmente diminuiram o crescimento da vegetação rasteira, que cobriu e protegeu o solo, mas também, pelas caminhadas dos animais; por meio dêstes foi cortado o revestimento da terra de modo que o sol atingiu o solo, dessecando-o, e a água pluvial e o vento na época da sêca, começaram a levar a terra humosa. Roendo as cascas das árvores e comendo as fôlhas, os cabritos diminuiram a mata. (Não encontramos sinais de incêndios.) Logo o lençol subterrâneo da água caiu e numerosas plantas desapareceram em grandes extensões. (Fatos paralelos conhecemos dos países mediterrâneos). Os porcos, em busca de raízes, fossaram a terra abrindo ainda mais o revestimento do solo; êstes lugares, com 1 a $2 \mathrm{~m}$ de largura e 3 a 5 de 
comprimento, encontramos freqüentemente, e sempre observamos a maneira com que a erosão começa o seu trabalho cortando em seguida novas ravinas. Quanto mais profundo êste sulco pluvial, tanto maior é a área que perde tôda a umidade. Observamos, no Morro do Paredãc, nos dois lados de uma ravina de $3 \mathrm{~m}$ de profundidade e $5 \mathrm{~m}$ de largura, faixas entre 8 e $10 \mathrm{~m}$ de largura sem qualquer vegetação (fig. 4). Neste

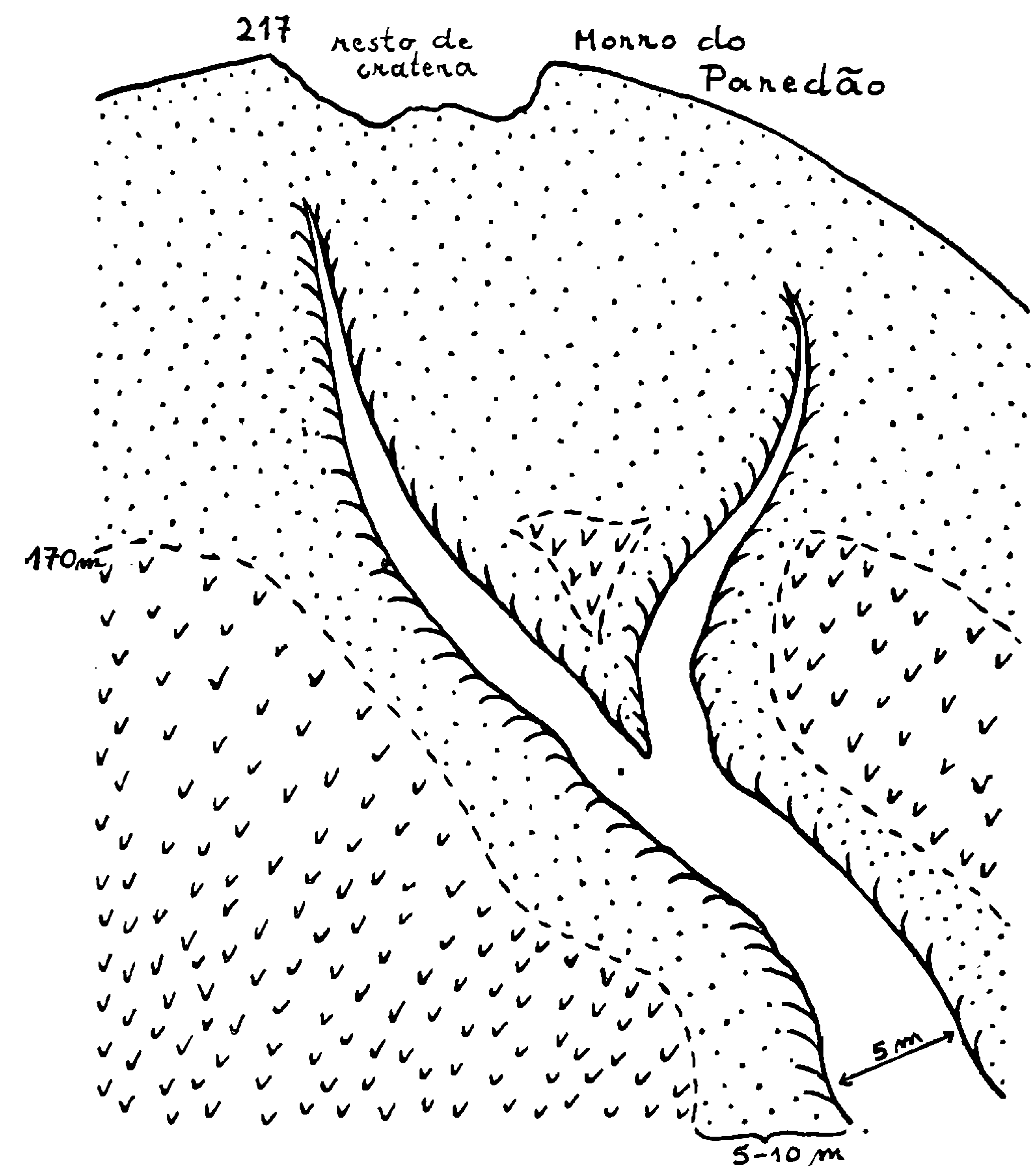

Fiz. 4 - Esquema de uma ravina do Morro do Paredão.

mesmo morro, a vegetação termina em 150 a $170 \mathrm{~m}$ de altitude; em cima desta linha até o cume, perto da cratera, não encontramos nenhuma planta viva; mas aí, a $217 \mathrm{~m}$ de altitude, aparecem ainda antigas raízes de Waltheria americana a $30 \mathrm{~cm}$ de profundidade.

No vale que entra na Praia das Tartaguras, entre Morro do Paredão, Pão-de-Açúcar, Picos N. S. de Lourdes e do Vigia e Morro das Tartaguras, encontramos quantidades de Mamoeiros (planta introduzida). Apenas três exemplares estão vivos, o resto é morto. O mesmo fato observa-se perto das habitações e no vale do córrego da Praia dos Portuguêses. Isto indica que estas plantas, em épocas passadas, há apenas poucos anos, encontraram aí condições muito mais favoráveis do que hoje.

Na Praia das Tartarugas, o vento constante do mar para a terra está transportando grande volume de areia que se desloca permanente- 
mente em direção ao Pico do Vigia, formando uma verdadeira duna migratória cujo cume está, hoje, já perto do citado pico.

Em 1916 foram indicados 5 córregos permanentes: um na Praia dos Portuguêses, três na Praia do Príncipe e um na Enseada da Cachoeira. Em 1950 foram encontrados sòmente dois: o da Praia dos Portuguêses e o da Enseada da Cachoeira. Nós encontramos:

Um córrego na Praia dos Portuguêses com atualmente 5 a 8 litros por segundo que abastece as habitações;

Os córregos da Praia do Príncipe não deixaram nenhum sinal da sua antiga existência; encontramos neste lugar, perto do marco de Benjamin Constant, uma pedra úmida da qual pinga algumas gotas de água, que logo desaparece na cinza vulcânica; de todos os lados convergem os trilhos de cabritos e carneiros para êste lugar, um sinal de que êste é o único ponto com água doce em tôda região;

$\mathrm{O}$ repórter Arnauld Pierre, passando do Pico de Trindade em direção aos Cinco Farilhões, encontrou um córrego que leva as águas dos Picos Desejado e de Trindade para o mar, e viu outro menor que desce dos Picos Sapé e Verde. Um terceiro com muito pouca água existe entre os Cinco Farilhões.

A existência permanente dêstes fios de água depende da vegetação. Esta, por sua vez, será destruída em poucos anos pela erosão que ataca em grande escala já as elevações mais altas, como se pode ver, aproximando-se do alto mar: grandes partes das paredes desmoronaram recentemente, as respectivas marcas são bem visíveis. Cada tentativa da vegetação de recuperar o terreno perdido é cortada pelos animais; as ciuas pequenas matas existentes no Pico Desejado e no Pico de Trindade estão em plena regressão, como provam os troncos caídos e a galharia morta encontrados nas suas vertentes.

Para salvar a terra, a ilha precisa de duas operações imediatas:

1. eliminar todos os animais introduzidos: Porcos, Cabritos e Carneiros; a carne pode ser aproveitada;

2. plantar árvores resistentes ao longo e, especialmente, na cabeceira do córrego da Praia dos Portuguêses para proteger o solo dêste vale.

Além de árvores, deve ser interessante plantar capim, ciperáceas e outras plantas que revestem o solo; em cada caso, porém, exclusivamente plantas tais que sejam componentes da flora original da ilha, pois por espécies introduzidas corremos novamente o perigo de desequilibrar a composição sociológica primitiva, adaptada ao clima da ilha.

\section{Observações climatológicas}

Tôdas estas observaçōes biológicas são feitas na época do inverno. Infelizmente não conhecemos ainda nada da climatologia da ilha. Com a construção de postos meteorológicos obteremos, depois de um ano de funcionamento, um aspecto, ainda provisório, da distribuição e 
quantidade de precipitação. Isso já permite algumas conclusões mais exatas sôbre a possibilidade de recuperar a terra, hoje perdida pela erosão. As observações sôbre a intensidade e direção principal dos ventos são, também, de grande interêsse. Mas um ciclo de um só ano de observações meteorológicas não é suficiente, pois não sabemos, entretanto, nada sôbre a periodicidade do clima, que é de grande importância não sòmente a respeito da ilha, como também para os nossos conhecimentos sôbre a climatologia do continente e do oceano.

Observamos, do ponto de vista meteorológico, alguns fatos interessantes que se referem a ilha bem como ao continente:

Durante tôda a época da nossa viagem, existia uma camada de inversão em aproximadamente $1.500 \mathrm{~m}$ de altitude, evitando a convecção subir mais e causando uma estratificação das nuvens neste nível. Em virtude disso as precipitações são limitadas, e realmente cairam apenas poucas chuvas passageiras sôbre o mar e a ilha.

Sôbre os fatôres, que contribuem para a formação da citada inversão térmica, ainda existem algumas dúvidas. A versão mais provável, a meu ver, é a parcialmente mencionada por Serra e Ratisbonna (1942, Min. Agric., Serv. Meteorol.. As massas de ar da América do Sul), interpretação baseada nas observações do "Meteor" e sondagens em Fernando de Noronha e na costa nordeste do Brasil. Passo, em seguida, a apresentar um esquema dêste fenômeno meteorológico, até agora não publicado numa maneira generalizada, como pude verificar na bibliografia disponível:

1. Num corte meridional, aproximadamente ao longo de $20^{\circ} \mathrm{W}$ (fig. 5) observamos, nas calmas equatoriais (C.E.), que o ar aquecido sobe até $8.000 \mathrm{~m}$ ou mais. Êste ar é substituído por outro que vem do sul, formando-se então um vento permanente desta direção que, aliás, pelo movimento da terra para leste passa a soprar de SE para NW (efeito de Coríolo). É o conhecido alísio. O ar acima de $8.000 \mathrm{~m}$ se desloca em direção contrária, formando o contra-alísio que, na zona das calmas tropicais (C.Tr.), desce, substituindo a massa que, daí, foi para o NW. Esta descidá e forçada pelo ar frio (polar-atlântico, PA) que se encontra, conforme a estação, entre $40^{\circ}$ e $50^{\circ} \mathrm{S}$. Os ventos do alísio compõem-se de duas massas bem diferenciadas, uma em baixo, outra em cima, de, aproximadamente, $1.500 \mathrm{~m}$ de altitude sendo separadas as duas pela inversão citada.

2. Num corte, na direção de $\mathrm{E}$ para $\mathrm{W}$, à altitude de $20^{\circ} \mathrm{S}$ (fig. 6 ), encontramos acima de $8.000 \mathrm{~m}$ o contra-alísio, embaixo as duas massas do alísio com a inversão que, perto da costa da África, começa perto do nível do $\operatorname{mar}\left(10^{\circ} \mathrm{E}\right)$ e sobe logo para atingir $500 \mathrm{~m}$ de altitude, subindo depois, mais lentamente, até chegar a uma altitude de $2.000 \mathrm{~m}$ perto da costa do Brasil $\left(40^{\circ} \mathrm{E}\right)$. A massa embaixo da inversão é úmida, de boa visibilidade, de composição instável e com ventos constantes e mais 




Fig. 5 - Esquema da circulação sôbre o Atlântico entre o equador e 40" S. Formação do Alísio.

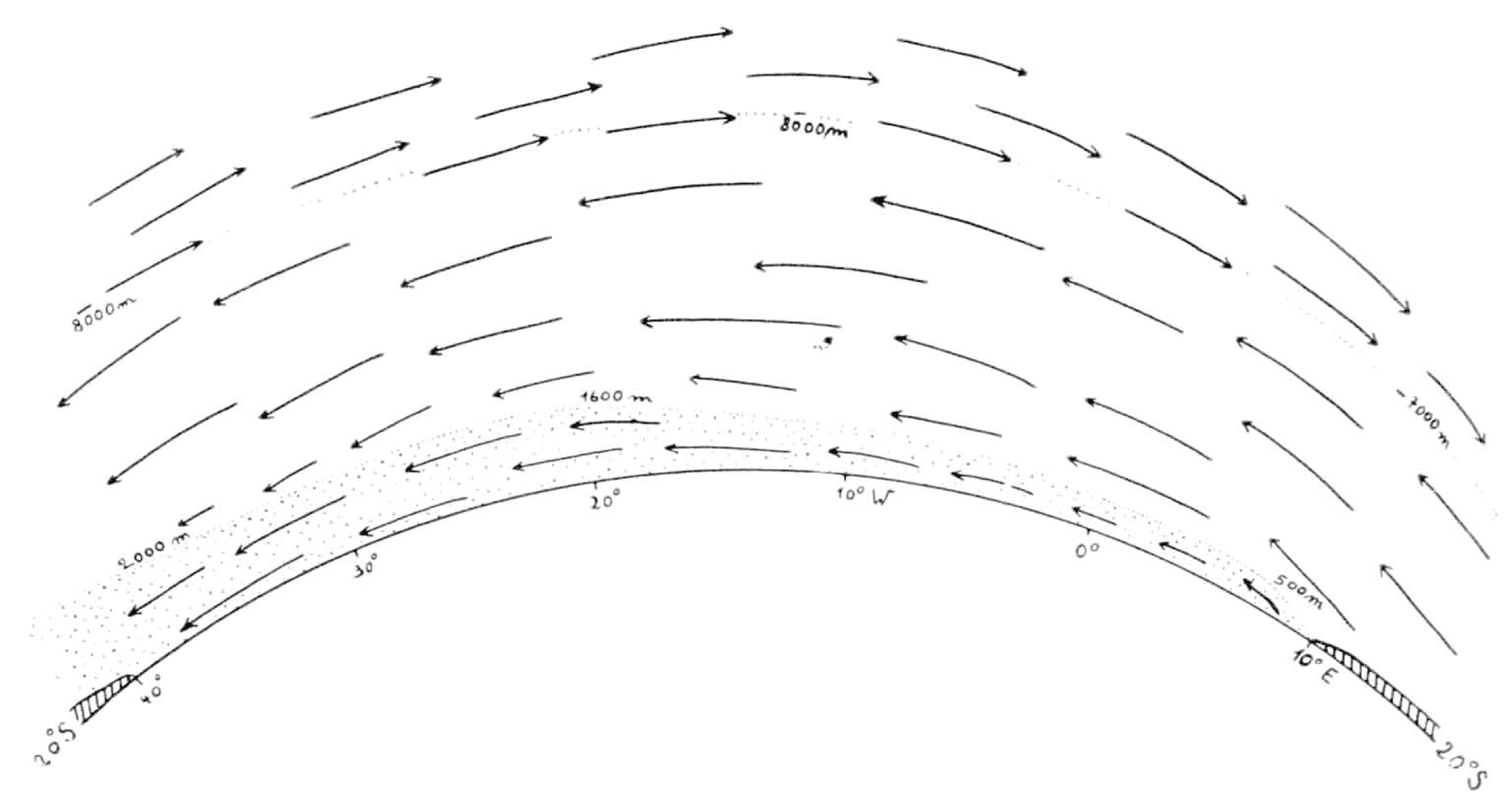

Fig. 6 - Perfil da atmosfera sobbre o Atlântico entre África e Brasil; as direçóes das setas do movimento do ar correspondem à direção $\mathrm{SE}$ - NW. 
ou menos fortes. Em cima da inversão o ar é sêco, com turvação nítida (bem visível na Ilha de Trindade), de composição estável e com ventos, pelo menos nas camadas inferiores, mais moderados. O valor da inversão perto da costa africana é aproximadamente de $\mathrm{n}^{0}+8^{\circ}$, perto da costa do Brasil de $\mathrm{n}^{0}{ }_{7}-0^{\circ}$, apresentando sôbre o oceano valores intermediários. Podemos, conforme êstes dados, reconstruir as curvas de temperaturas sôbre a costa da África, sôbre a Ilha de Trindade e sôbre a costa do Brasil (fig. 7), demonstrando, além da inversão do solo (I) o

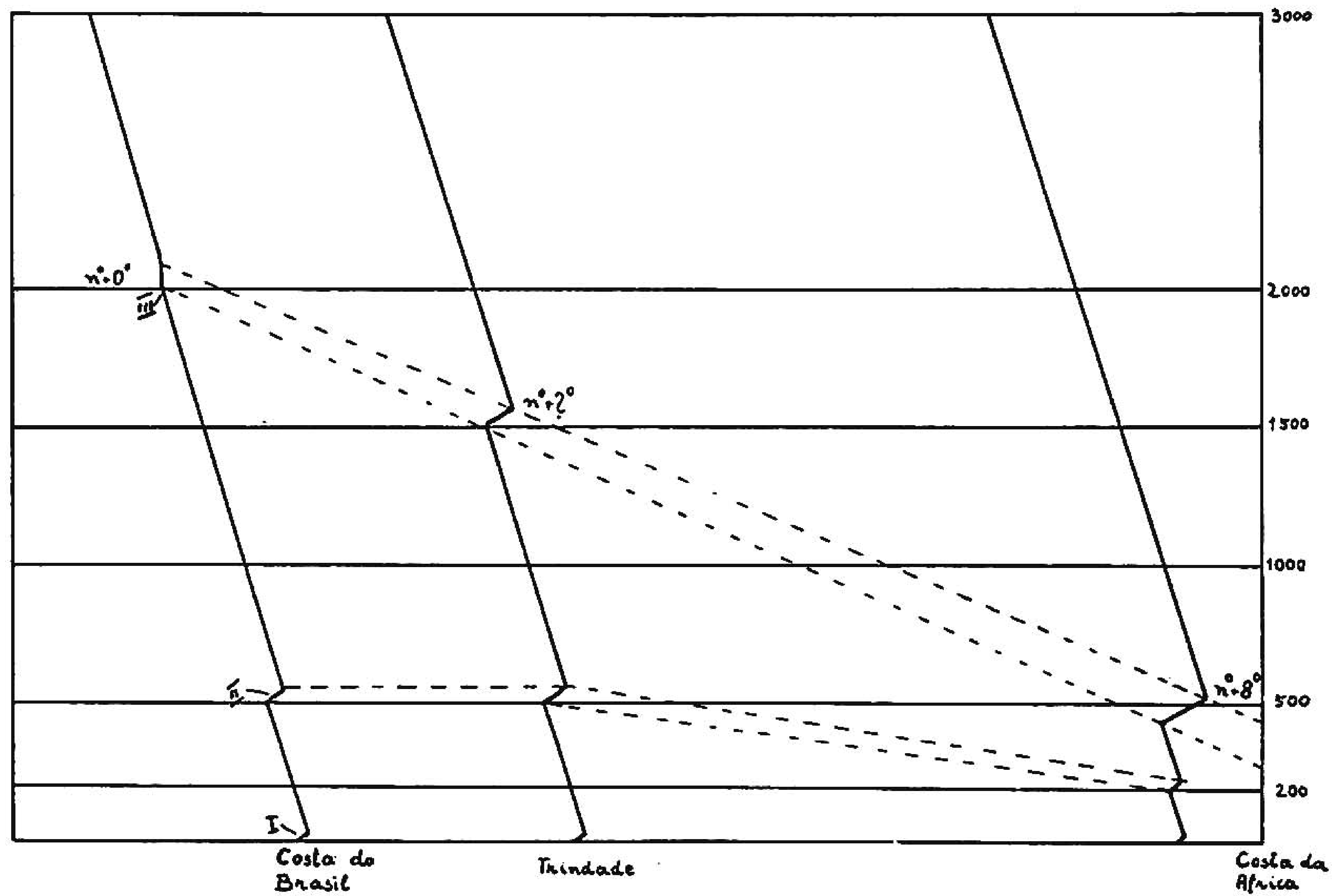

Fìg. 7 - Esquema das inversóes térmicas sóbre o Atlántıco entre Africa e Brasil.

limite inferior da formação de nuvens (II) e a inversão do alísio (III) que, por sua vez, representa o limite superior das nuvens.

3. Controlando a origem do ar dos alísios podemos identificar: a massa inferior é de origem puramente marítima, que passa sôbre a corrente fria de Benguela entre $10^{\circ}$ e $5^{\circ} \mathrm{E}$, e depois sôbre a corrente quente do Brasil $\left(20^{\circ}\right.$ a $\left.40^{\circ} \mathrm{W}\right)$, onde é forçada a levantar-se pelo aquecimento. A massa superior é de origem continental africana, aquecida e sêca durante a trajetória sôbre as partes ocidentais dêste continente (Desertos de Namib e Kalahari) e carregada de poeira continental.

4. O aspecto do céu na Ilha de Trindade corresponde exatamente aos expostos nos itens 1 a 3 (fig. 8): o limite inferior das poucas 
nuvens, que se formam nesta zona de alta pressão, encontramos em 500 a $600 \mathrm{~m}$ de altitude. A conveccão termina em $1.500 \mathrm{~m}$ (aproximadamente, faltam-nos ainda os dados de radiossonda-

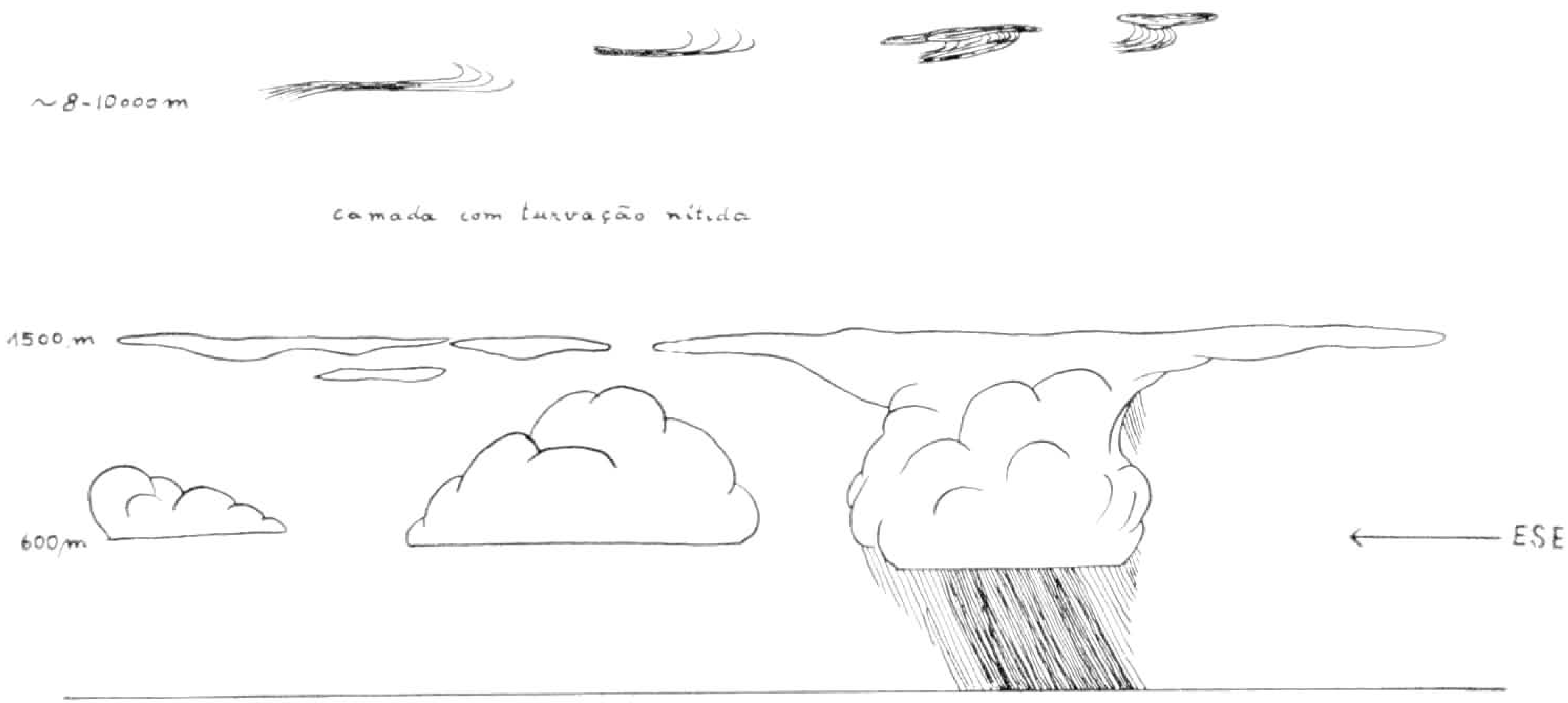

Fig. 8 - Aspecto e-quematizado do céu sôbre a Ilha de Trindade

gem da ilha a fim de conferirmos as nossas observações a ôlho nu), observando-se uma intensa estratificação embaixo da inversão. As acumulações das nuvens de convecção dão chuvas sôbre áreas limitadas. Acima de $1.500 \mathrm{~m}$ não encontramos nu-

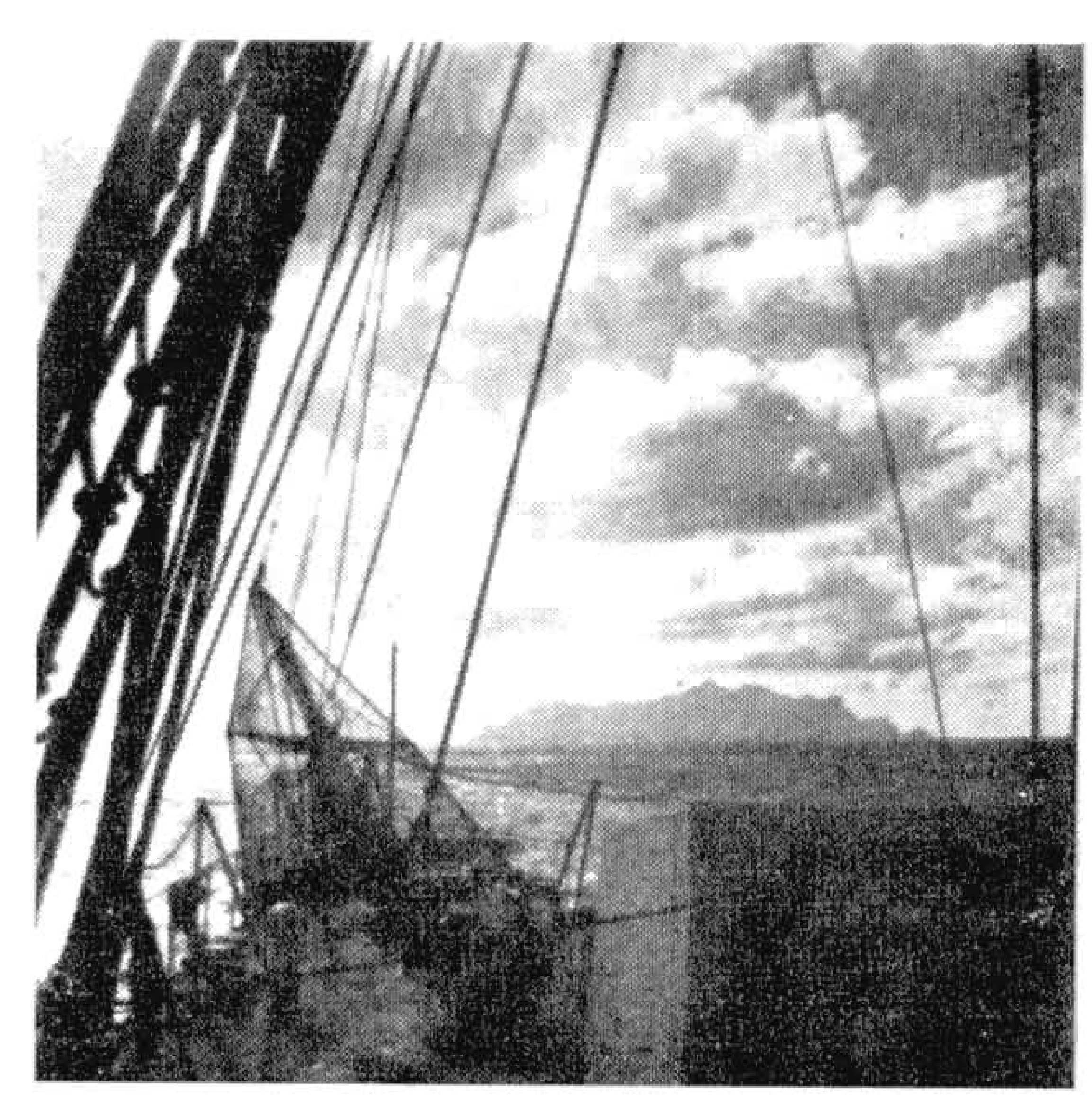

Fig. 9- Formação de cúmulos sóbre a Ilha de Trindade (6 horas)

vens do nível médio. Mas o ar possui uma turvação bem visível, observando-se o horizonte dos altos de picos da ilha no sentido com os raios do sol. Acima de $8.000 \mathrm{~m}$ ou mais são freqüentes os cirrostratos e, às vêzes, os cirrocúmulos, deixando ainda observar, muitas vêzes, uma certa instabilidade. 
5. Este aspecto modifica-se no caso em que o ar frio do sul se estenda mais para o norte e aumenta a massa de ar pesado embaixo da inversão, forçando esta a subir até $2.000 \mathrm{~m}$. Nesta posição a inversão permite uma formação mais forte de nuvens de convecção de modo que a precipitação chegue à ilha em quantidade mais elevada..

Em relação direta com a direção dos ventos, observamos formações de nuvens sôbre as encostas dos picos, trazendo uma certa quantidade de água que se ali condensa.

Comparações entre direção do vento e pressão barométrica permitem conclusões đairetas sôbre a translocação do anticiclone atlântico e, com isto, previsões sôbre os movimentos das frentes trazidas pelos ciclones continentais com uma antecedência de alguns dias. Estas previsões são necessárias não sòmente para o serviço nacional de meteorologia, porém muito interessante para a navegação internacional. Um pôsto climatológico permanente na ilha modificará muitos dos nossos conhecimentos, ainda incompletos, sôbre os movimentos de massas de ar do Atlântico, sôbre a influência do ar frio de origem africana (corrente de Benguela) ao nosso clima e sôbre a zona dos alísios cuja fronteira meridional, no inverno, corresponde à região da ilha e, no verão, passa para o sul de Trindade. A fim de controlar as propriedades do clima do Atlântico, por meio de radiossondagem, a ilha de Trindade é o único lugar existente nesta zona.

Para formar um aspecto completo das condições biológicas da ilha, necessitamos ainda observações em outras épocas do ano e, para fim de comparação, uma visita do arquipélago de Martin Vaz cujas fauna e flora e aspecto geomorfológico não foram modificados pela ação do homem.

As fotografias, apresentadas neste trabalho, são da autoria do repórter Waldyr Santos Braga, Rio de Janeiro, a quem agradeço cordialmente.

\section{Resumo}

1. As observações faunísticas, florísticas e climatológicas formam ainda um aspecto incompleto da Ilha de Trindade. Necessitamos ainda de observações em outras estações do ano e, também, do arquipélago de Martin Vaz, bem como de dados meteorológicos de alguns anos consecutivos.

2. A vegetação da ilha e, concomitantemente, a parte fértil da terra, estão desaparecendo pela influência de animais introduzidos (porcos, cabritos e carneiros) que se alimentam das poucas plantas, destruindo o revestimento do solo e, assim, acelerando a erosão. Para pos- 
sibilitar habitações permanentes em pequena escala, são necessárias duas operações imediatas :

a) diminuir ou, ainda melhor, eliminar por completo êstes animais cuja carne é comestível;

b) plantar árvores pelo menos na parte habitada e no córrego que abastece a guarnição com água.

3. O solo é rico em minerais, porém pobre em micro-organismos. Para horticultura basta uma adubação por estrume natural e cal, que existe em quantidade na ilha em forma de recifes coralinos.

4. É explicada a formação provàvel da inversão dos alísios e, com isso, o clima sêco da ilha.

5. De vários pontos de vista (ecologia, climatologia, de navegacão e aviação, de previsão de tempo no continente, da pesca etc.), torna-se aconselhável manter na ilha um pôsto permanente de meteorologia e radiossondagem.

\section{ZUSAMM,ENFASSUNG}

1. Die faunistischen, floristischen und klimatologischen Beobachtungen geben einen nur unvollkommenen Anblick der Insel Trindade. Wir benoetigen noch Beobachtungen zu anderen Jahreszeiten, desweiteren einen Besuch der Inselgruppe Martin Vaz und ebenso meteorologische Daten aus einigen sich folgenden Jahren.

2. Die Vegetation der Insel und gleichzeitig der fruchtbare Teil der Erde verringern sich schnell unter dem Einfluss eingefuehrter Tiere (Schweine, Ziegen, Schafe), die sich von den wenigen Pflanzen ernaehren und dadurch die Bodenbedeckung zerstoeren und die Erosion beschleunigen. Um die Insel in kleinem Masstab bewohnbar zu erhalten, sind zwei Massnahmen unbedingt erforderlich:

a) die genannten Tiere verringern oder, besser noch, voellig ausrotten; ihr Fleisch ist verwendbar;

b) Pflanzen von Baeumen zumindest in der bewohnten Zone und am Wasserlauf, der die Garnison versorgt.

3. Der Boden ist reich an Mineralien, aber arm an Mikroorganisnien. Um Gartenbau zu ermoeglichen, genuegt eine Duengung mit natuerlichem Duenger und Kalk, der in Mengen auf der Insel in Form von Korallenriffs vorhanden ist,

4. Es wird die wahrscheinliche Art der Bildung der Passat-Inversion und damit das trockene Klima der Insel erklaert.

5. Von verschiedenen Gesichtspunkten aus (Oekologie, Klimatologie, Schiffahrt und Luftfahrt, Wettervorhersage auf dem Kontinent, Fischerei usw) ist es ratsam, auf der Insel eine dauernde Wetterstation mit Radiosonde aufrecht zu erhalten. 


\section{ESTAMPA 1}

Fig. 10 - Trindade, vista de oeste. A esquerda: Ponta Crista de Galo; à direita: Ilha da Racha e Ponta da Cachoeira. Formação das primeiras nuvens

Fig. 11 - Enseada dos Portuguêses. Em frente: Pedra do Tubarão; à direita: avalanche de mataçōes originados pelo desmoronamento do Pico 309. 




Fig. 10






\section{ESTAMPA 2}

Fig. 12 - Ancoradouro na Enseada dos Portuguêses com o NE "Almirante Saldanha" e a corveta "Solimōes". Vendo-se entre a arrebentação e a terra o banco coralino, na popa da corveta o flutuante para o desembarque. 


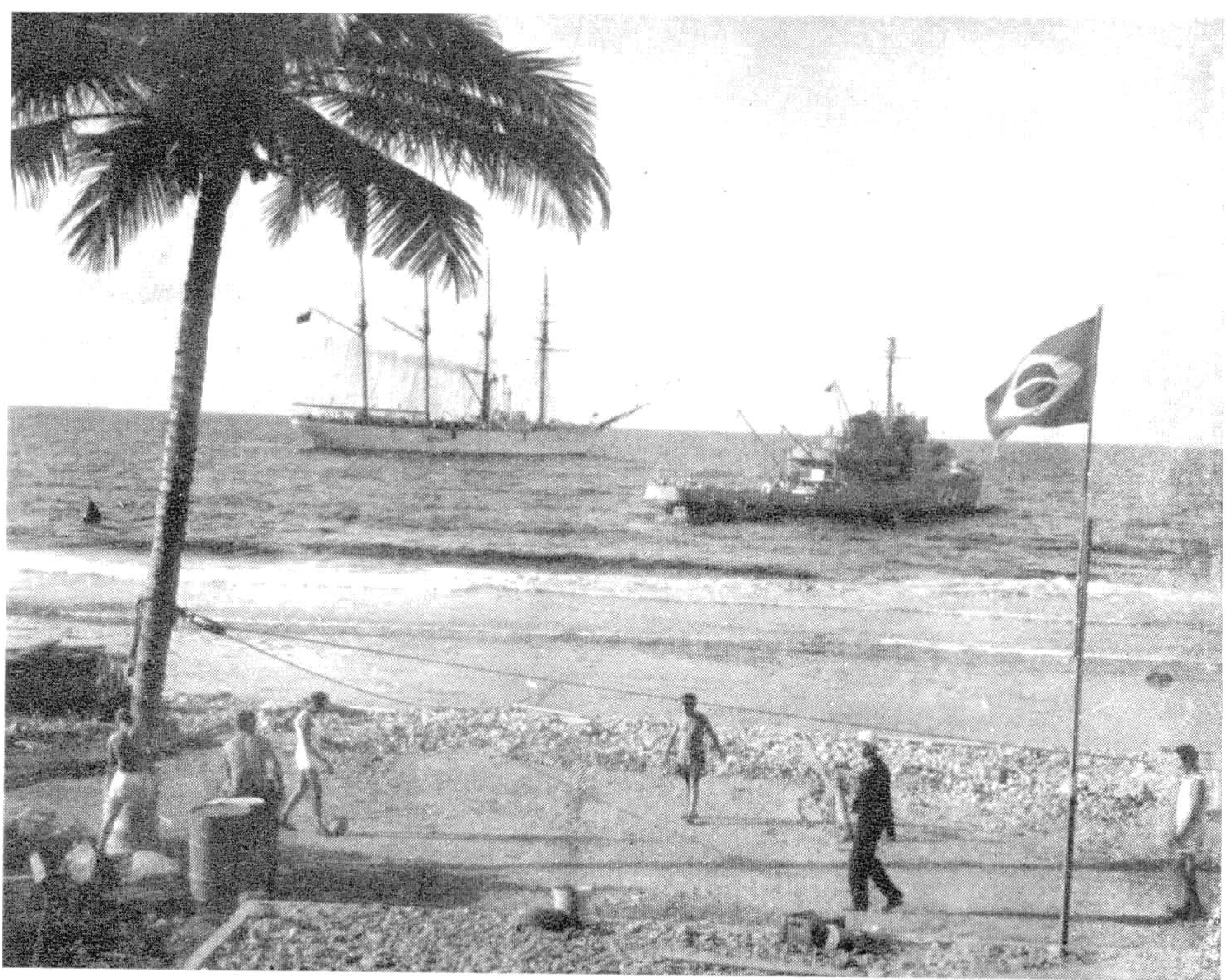

Fig. 12 
ESTAMPA 3

Fig. 13 - Arrebentaçāo no banco de corais.

Fig. 14 - Parcel das Tartarugas.

Fig. 15 - Praia do Paredão.

Fiy. 16 - Arrebentação, maré alta, seixos sôbre o banco coralino, na água os destroços de um barco avariado. 


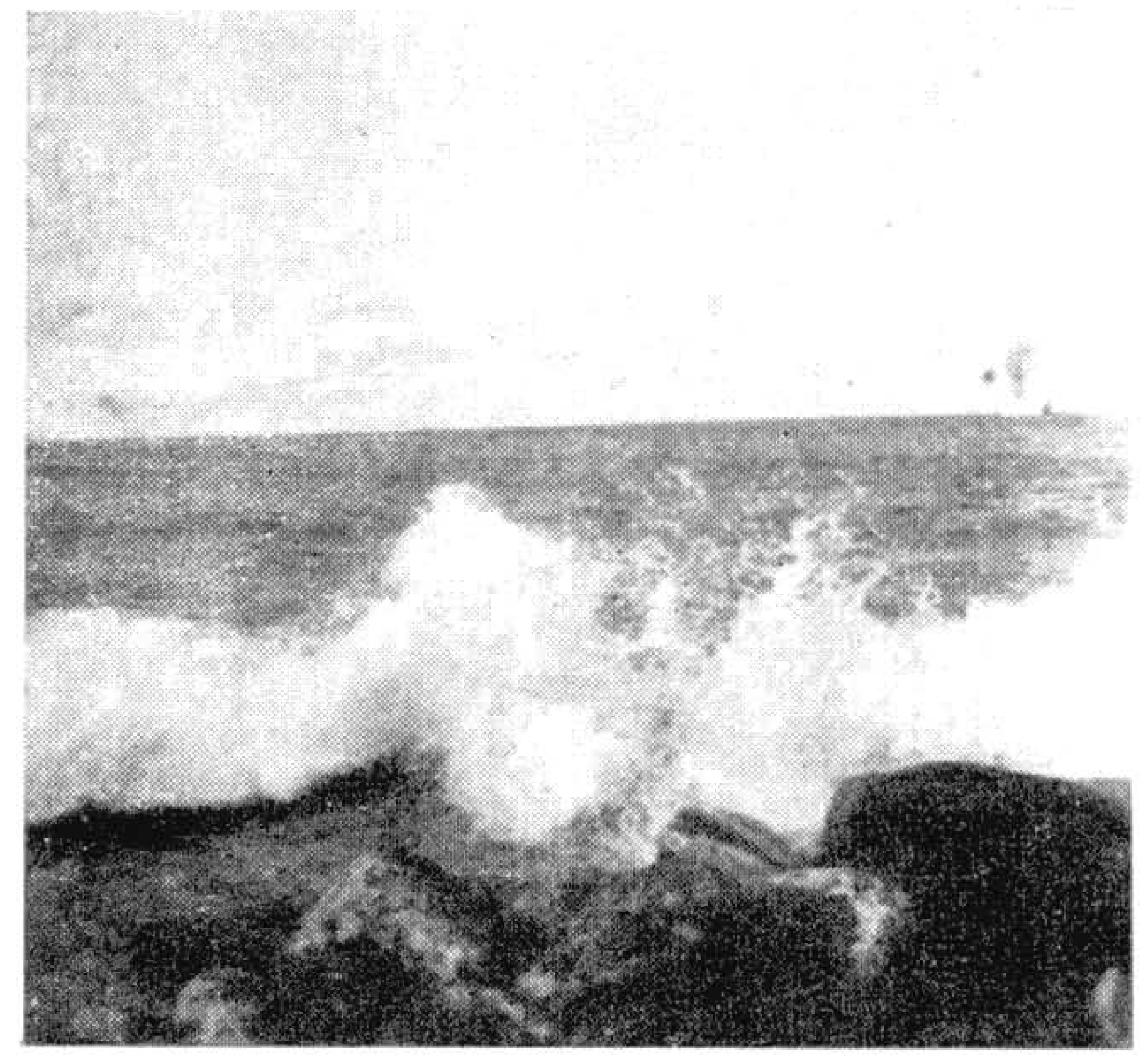

Fig. 13

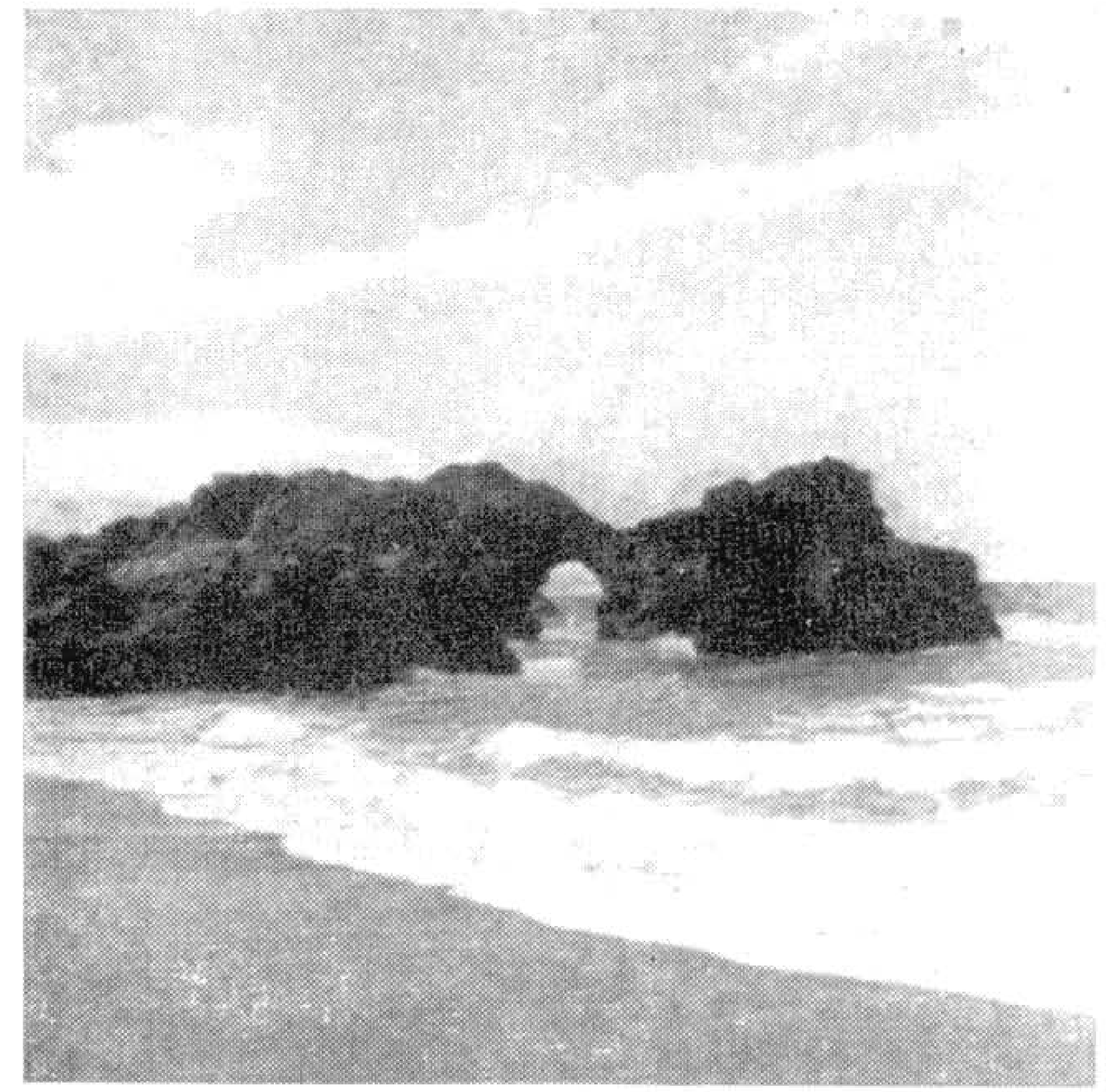

Fig. 15

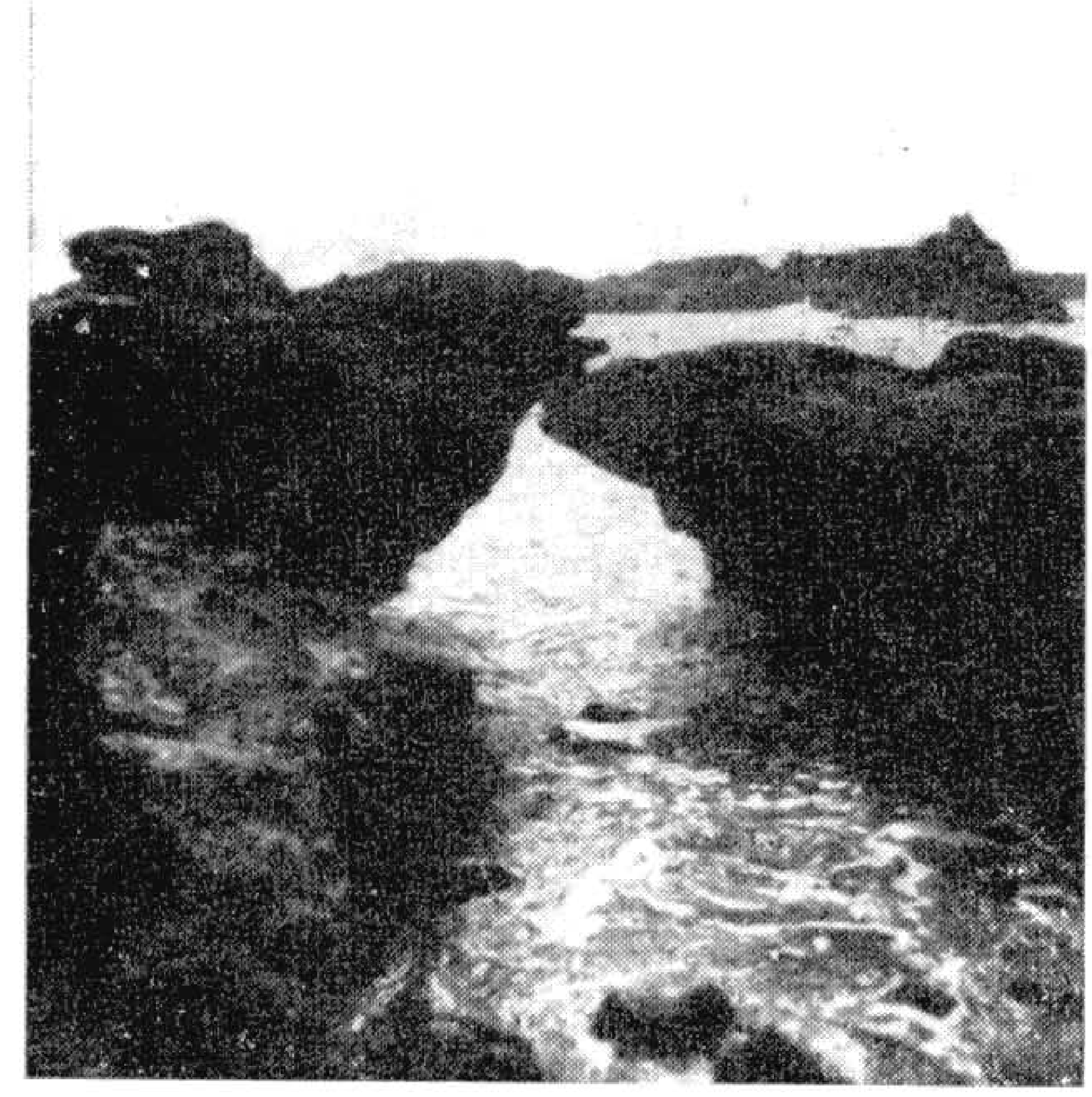

Fig. 14

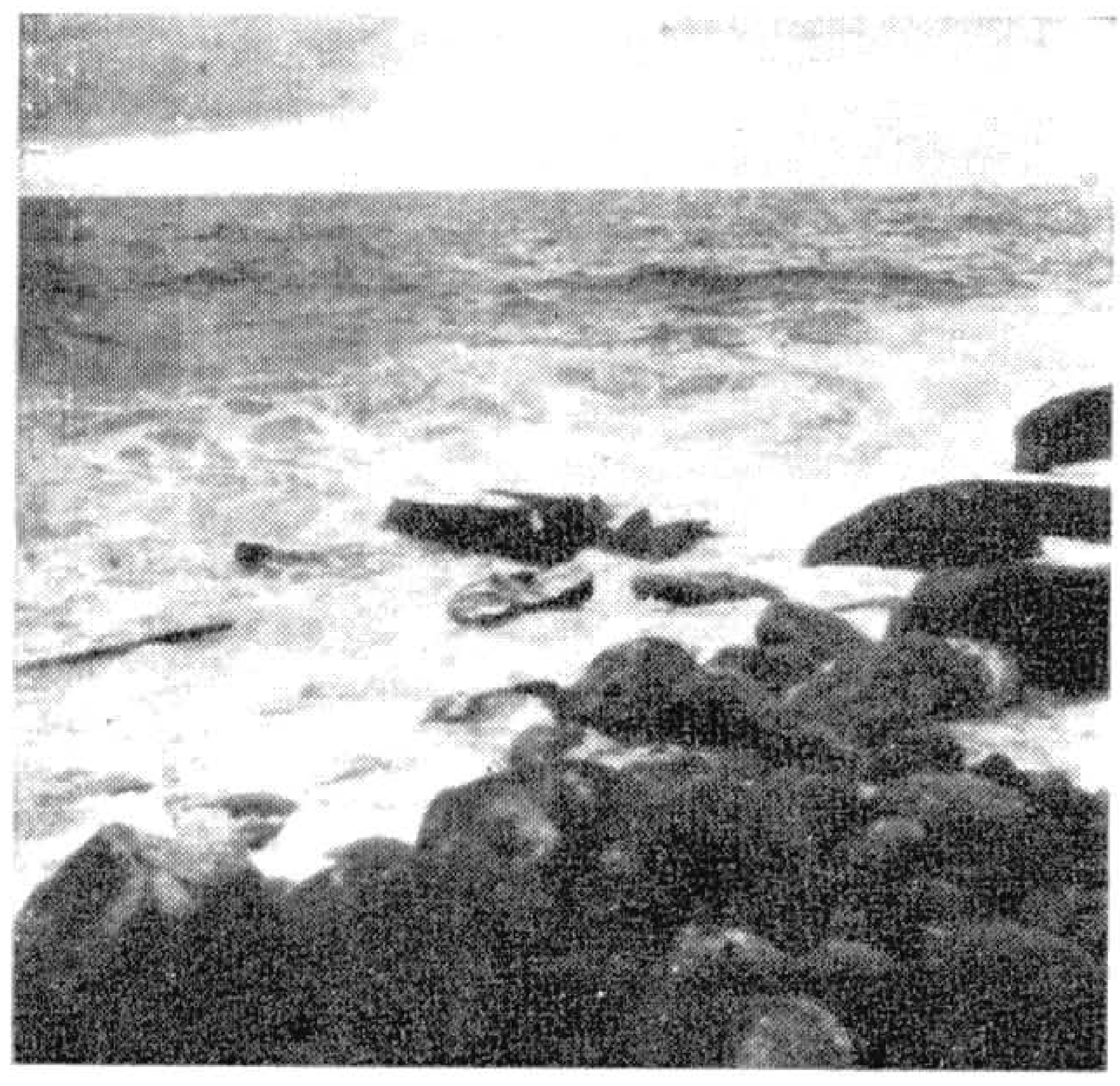

Fig. 16 
ESTAMPA 4

Fig. 17 - Túnel do Paredão.

Fig. 18 - Pão-de-Açúcar e Pico do Vigia com avalanche de mataçōes. 


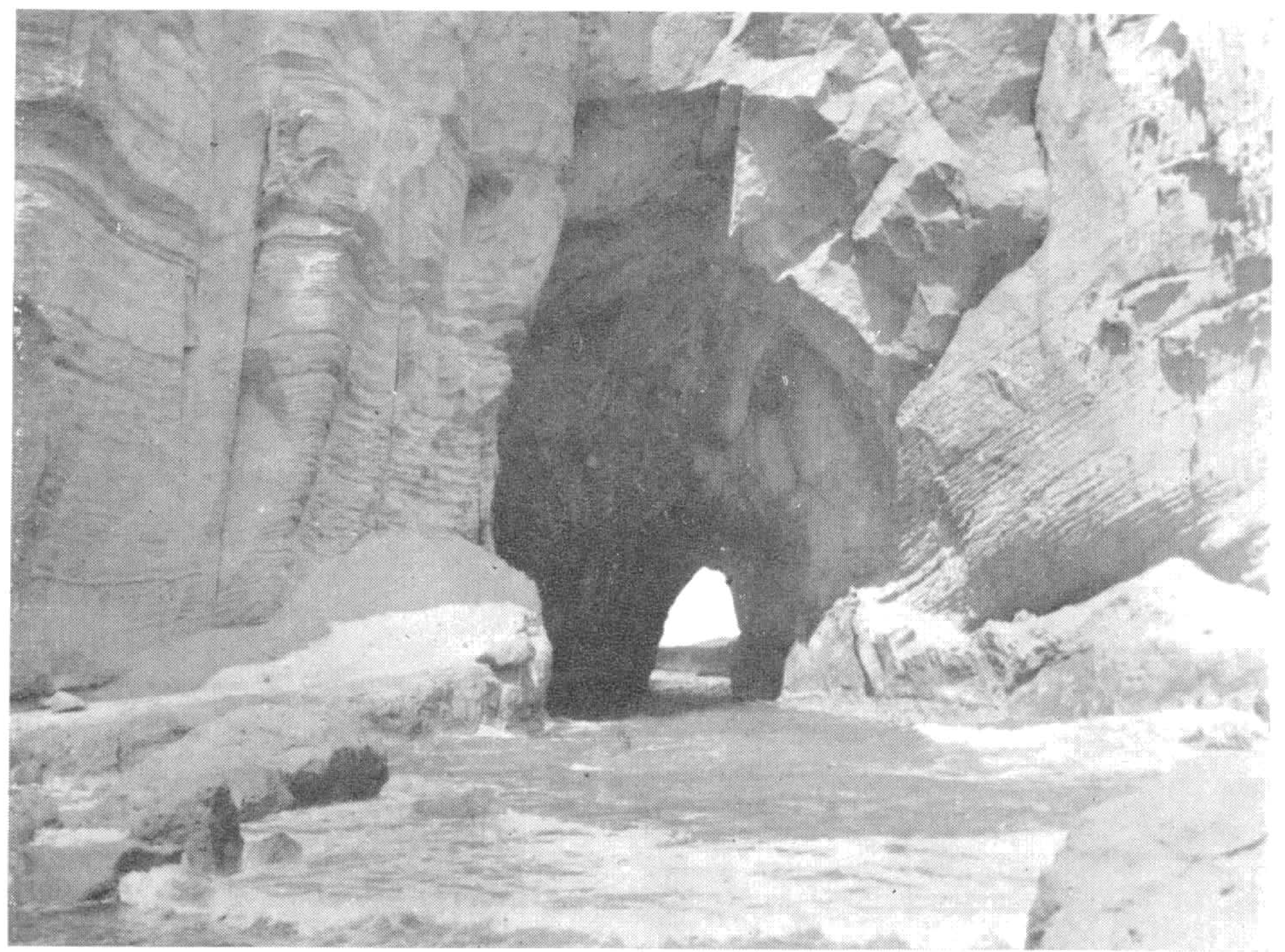

Fig. 17

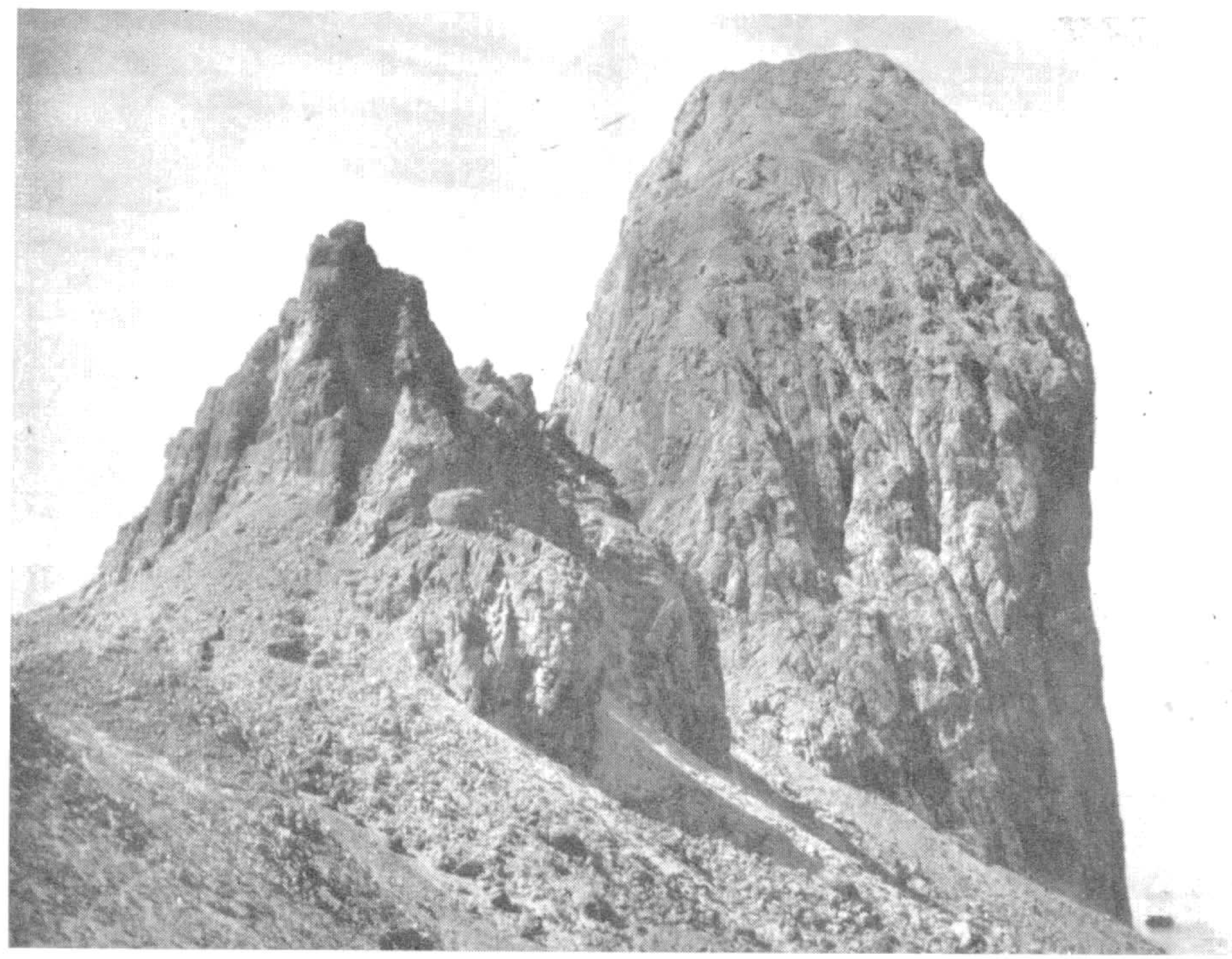

Fig 18 


\section{ESTAMPA 5}

Fig. 19 - Duna migratória entre Morro das Tartarugas e Pico N. S. de Lourdes.

Fig. 20 - Cirrostrato em, aproximadamente, $10.000 \mathrm{~m}$ de altitude sôbre o cemitério de Trindade (formaçōes de nuvens do contra-alísio).

Fig. 21 - Crista de Galo, visto de leste; estratificação de nuvens a, aproximadamente, $1.509 \mathrm{~m}$ de altitude (17 horas). 


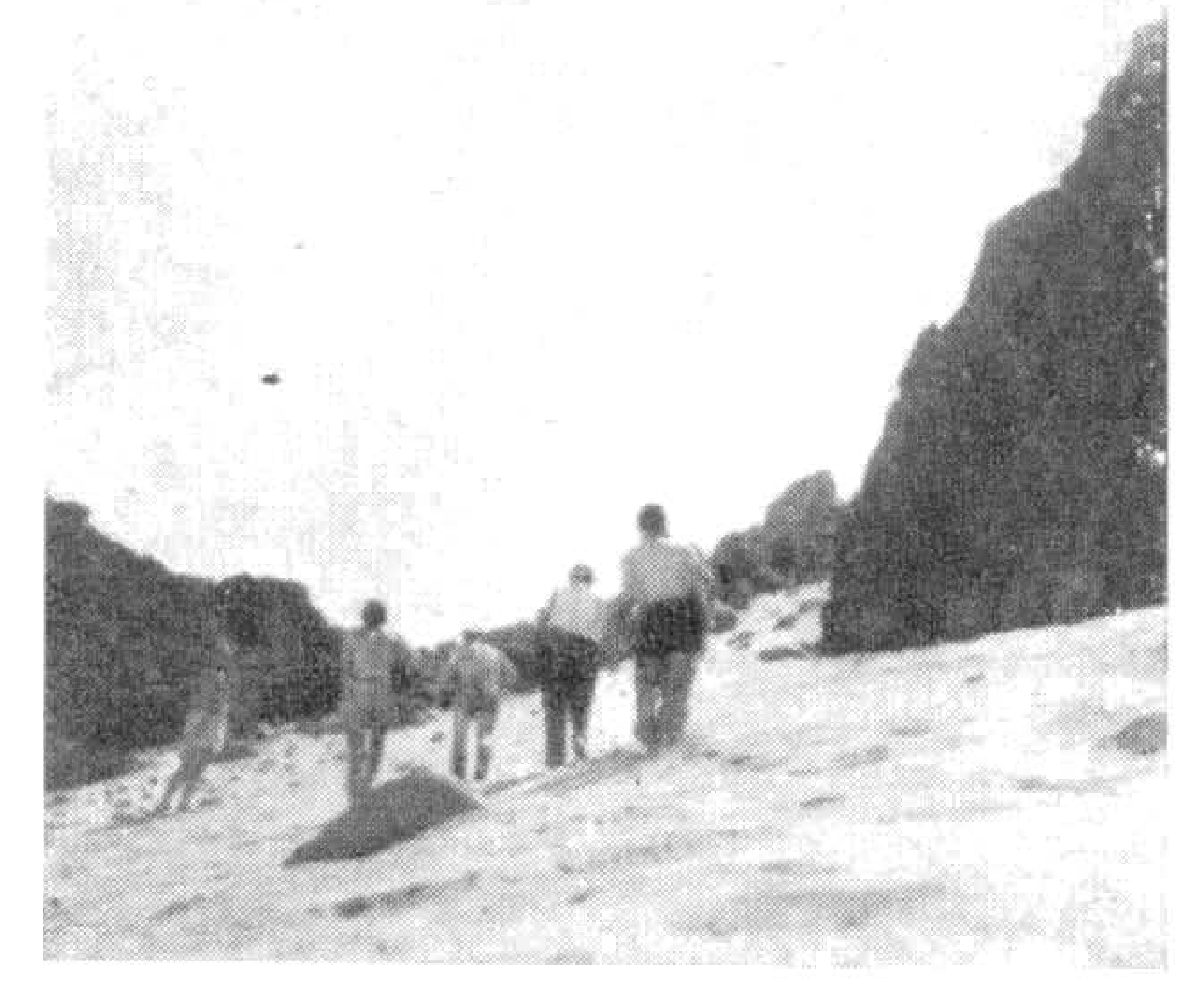

Fig. 19

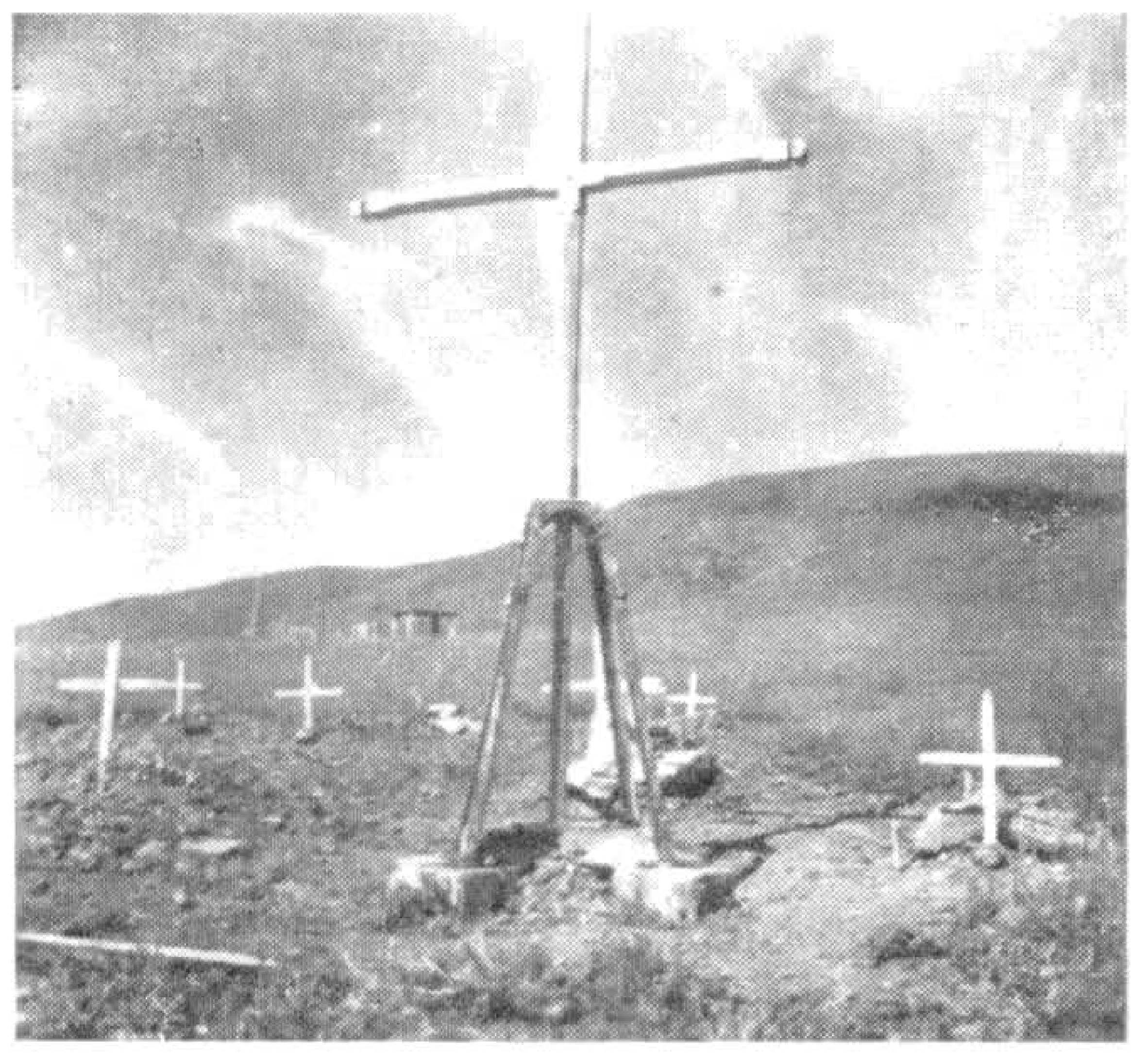

Fig. 20

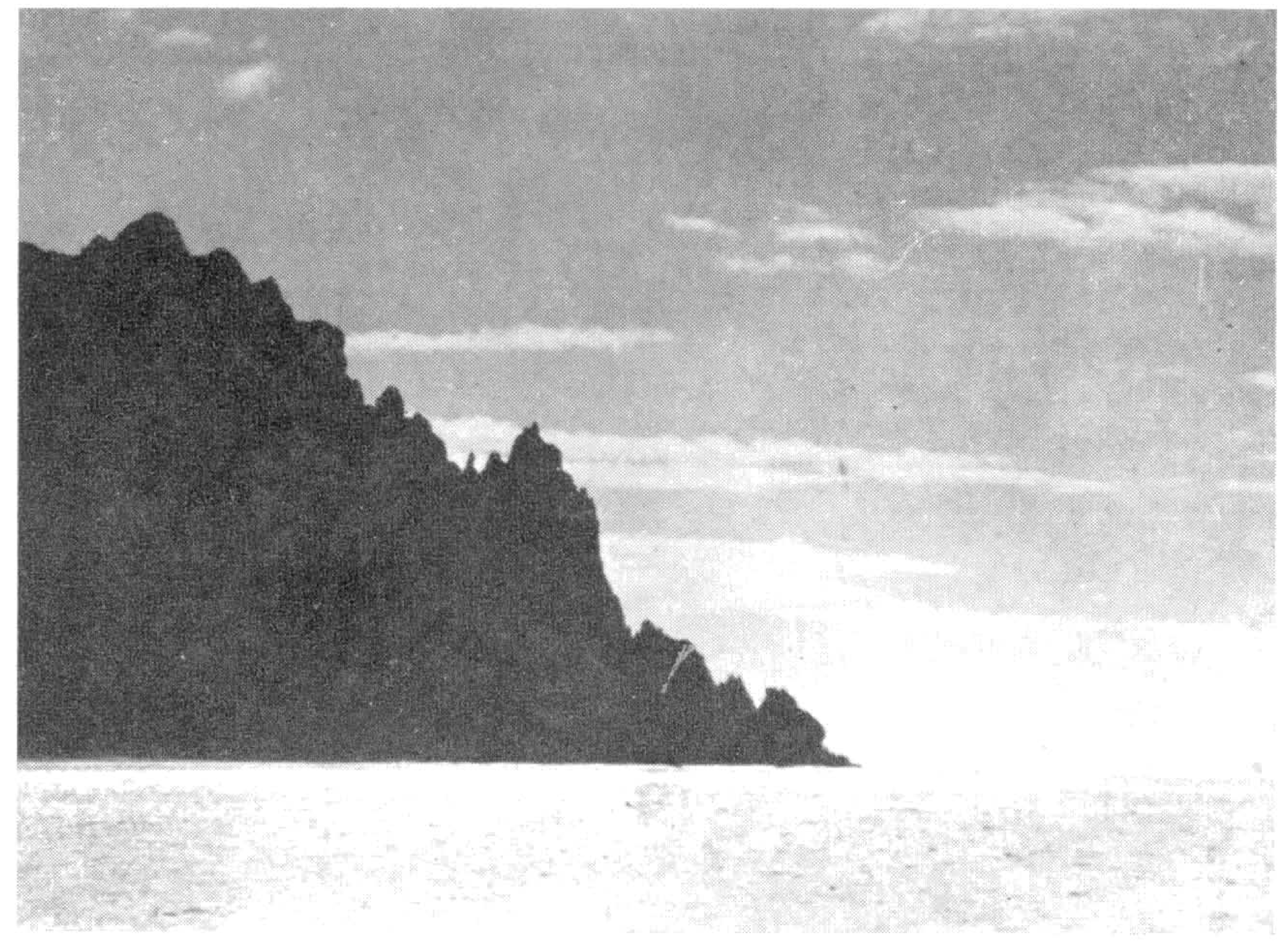

Fig. 21 